\title{
External ontogenetic changes of larval structures in Elachistocleis bicolor (Anura: Microhylidae: Gastrophryninae)
}

\author{
Fernanda N. Abreliano, Víctor H. Zaracho* \& María T. Sandoval \\ Laboratorio de Herpetología, Departamento de Biología, Facultad de Ciencias Exactas y Naturales y Agrimensura, Univer- \\ sidad Nacional del Nordeste, Av. Libertad 5470, 3400-Corrientes, Argentina; e-mail: victorzaracho@yahoo.com.ar
}

\begin{abstract}
Although the external larval morphology of many species of Microhylidae has been characterized, ontogenetic studies in the family are scarce and partial. In the present study, we describe the development of the oral funnel, external gills, external nares, operculum, spiracle, and adhesive organs of Elachistocleis bicolor with the aim to contribute to future ontogenetic, evolutionary, and phylogenetic studies. The development of E. bicolor is similar to that of other species with free-swimming tadpoles as Microhyla ornata, Dermatonotus muelleri and Uperodon globulosus. The ontogeny of the oral apparatus shows only the early stages of the pattern most common in anurans. After the invagination of the stomodeum, the anterior and posterior labia are defined, but the keratinized structures are not formed. The conical adhesive glands are similar to those of Physalaemus and Dendropsophus tadpoles, but in E. bicolor, these develop in contact with the posterior labium. The external nares remain closed during most of the larval phase. During ontogeny, the external gills are simultaneously covered by a transverse operculum fold, which later advances towards the posteromedial ventral region, forming the spiracle, while in Type IV larvae the operculum folds close from right to left, covering the right gill first. The distinct larval characters of Microhylidae appear between the last embryonic stages and the first larval stages. Therefore, the consideration of these stages can be of great value in future studies of anuran development in phylogenetic and evolutionary contexts. Ontogenetic studies in microhylid tadpoles are fundamental to identify heterochronic processes, to interpret the variability of larval structures, and to establish or reinforce hypotheses about the origin of larval structures.
\end{abstract}

Key words: anurans; development; spiracle; oral funnel; external gills; nares

\section{Introduction}

The ontogeny of an individual consists of a series of stages whose number could be considered infinite. However, operationally, it is necessary to quantify them in discrete stages, both to obtain a clear perception of the processes involved and to be able to make valid comparisons among different taxa (Lavilla \& Rougés 1992). In anurans, staging tables based mainly on morphological and physiological characters, are a condensed way to describe ontogenetic changes (Hall et al. 1997).

The family Microhylidae, widely distributed in the world, contains species with different reproductive modes, including direct development. In the case of species with exotrophic tadpoles, larvae exhibit distinctive morphological features, and are named Type II tadpoles (Orton 1953). The external larval morphology has been characterized in many species (e.g., Rada de Martinez 1981; Williams \& Gudynas 1987; Donnelly et al. 1990; Lavilla 1992; Kwet \& Di-Bernardo 1998; Wogel et al. 2004; Nascimento \& Skuk 2006; Rossa Feres \& Nomura 2006; Vera Candioti 2006; Grosjean et al. 2007; Langone et al. 2007; Lehr et al. 2007; Rodrigues et al. 2008; Mac Culloch et al. 2008; Bowatte \& Meegaskum- bura 2011; Magalhaes et al. 2012; Pereyra et al. 2013). However, ontogenetic studies in Microhylidae are scarce and partial, and highly contrast with what is known about species with Orton's Type IV tadpoles (Marinelli et al. 1985; Takahama et al. 1987; Thibaudeau \& Altig 1988; Fiorito de López \& Echeverría 1989; Hall et al. 1997; Zaracho et al. 2003; Nokhbatolfoghahai \& Downie 2005a, 2008; Altig 2006; Salica et al. 2011).

For Microhylidae, a development table with 29 stages based on external morphology changes has been proposed for Chiasmocleis antenori (Walker, 1973), a species whose larval life is adapted to bromeliads (Krügel \& Richter 1995). Also, different development tables have been proposed for Microhyla ornata (Duméril et Bibron, 1841) (Padhye \& Ghate 1989; Baorong et al. 1996; Shaolong et al. 1996; Shimizu \& Ota 2003; Xu \& Xu 2012). In adiditon, the normal development of $M$. ornata and Uperodon globulosus (Günther, 1864) has been described and compared following the stages of Gosner (1960) (Narzary \& Bordoloi 2013). Variations during larval development (stages 26-46), including information on external and internal morphology, have been described for Dermatonotus muelleri (Boettger, 1885) (Fabrezi et al.

* Corresponding author 
2012). The development of the operculum, the presence of external gills, tail structure, gut development and timing of forelimb emergence have been researched in Australopapuan microhylid species with direct development (Townsend \& Stewart 1985, Anstis et al. 2011).

Although microhylids present considerable ontogenetic diversity, the initial steps of embryogenesis show the standard pattern of cleavage in amphibians (Desnitskiy 2012). Thibaudeau \& Altig (1988) and Altig (2006) carried out an inclusive and general review of the origin and evolution of the oral apparatus in anuran tadpoles, including those of Microhylidae, whereas Donnelly et al. (1990) reported the morphological variations in free-swimming microhylid larvae. Nokhbatolfoghahai \& Downie (2005a) described the narial development of Elachistocleis ovalis (Schneider, 1799) and also analyzed the development and morphology of the adhesive gland and external gills of the same species (Nokhbatolfoghahai \& Downie 2005b, 2008). These studies revealed five patterns of adhesive gland morphogenesis and an important diversity at the anatomical and cellular levels in the extent and length of the external gills.

Previous works in Elachistocleis bicolor (GuérinMeneville, 1838) tadpoles have described the external larval morphology (Williams \& Gudynas 1987), the chondrocranium and hiobranquial apparatus (Lavilla \& Langone 1995), the internal oral morphology (Echeverría \& Lavilla 2000), the shape variation in the paired oral flaps (Laufer et al. 2013), and ontogenetic changes in the spiracle and vent tube orientation during late larval stages (Lavilla \& Langone 1991).

In this work, we describe the development of the oral funnel, external gills, external nares, operculum, spiracle, and adhesive organs of E. bicolor. These data may contribute to future ontogenetic, evolutionary, and phylogenetic studies.

\section{Material and methods}

Embryos and tadpoles of Elachistocleis bicolor were collected in Corrientes, Argentina $\left(27^{\circ} 28^{\prime} 04^{\prime \prime} \mathrm{S} ; 58^{\circ} 46^{\prime} 52^{\prime \prime} \mathrm{W}\right)$, between October 2009 and March of 2010. They were collected from small temporary ponds of $30 \mathrm{~cm}$ of maximum water depth, formed after copious rains. These ponds were in a grassy area subject to human activity or intervention.

Embryos and tadpoles were kept in plastic bowls according to Lavilla \& Rougés (1992). Larvae were placed in bowls with water of the same pond where they were collected, also including some aquatic plants. The water was renewed periodically. Embryos and tadpoles were fixed periodically in 10\% formalin every 2 hours for embryonic stages and every 3 hours for the larval stage (until stage 26) and every 24,48 or 72 hours up to metamorphosis. Embryos and tadpoles were analyzed by stereoscopic microscope and Scanning Electron Microscope (SEM). For this, the specimens were washed with $0.1 \mathrm{M}$ phosphate-buffer solution series, treated with a graded acetone series, then criticalpoint-dried and coated with gold. Specimens were examined using a Jeol JSM-5800 LV SEM. Embryos and tadpoles were deposited in the herpetological collection of the Universidad Nacional del Nordeste (Corrientes): UNNEC 11045-11067. Anatomical terminology follows Altig \& McDiarmid (1999) and stages of development are based on the development table of Microhyla ornata (Shimizu \& Ota 2003) since they better agree with the development of structures such as operculum and spiracle in Orton's Type II larvae.

\section{Results}

\section{Development of the oral funnel}

The development of the oral funnel initiates at stage 18 , with the invagination of the stomodeum in the anteroventral region, between the adhesive organs and the olfactory pits (Fig. 1A). At stage 22, the stomodeal invagination becomes deeper and presents a continuous posterior, longitudinal groove (Fig. 1B). By stage 23, the stomodeum opening is circular in shape (Fig. 1C), and by stage 24 it becomes semicircular and is placed in terminal position. In this last stage, a thick, anterior flange whose posterior ends are continuous with the adhesive glands, appears (Fig. 1D). This structure corresponds to the oral anterior labium bud and has epidermal ciliated cells. At stages 25-26, a posterior flange, which corresponds to the posterior labium bulge, develops (Figs 1E, F). From stage 27 to 32 , the anterior labium develops two lateral thickenings, corresponding to the primordia of the labial flaps (Figs 1G, $\mathrm{H})$. During subsequent stages, the oral funnel grows in size and the only noticeable change is the shape of the labial flaps. Although the change is gradual, the labial flaps are mainly short and semicircular between stages 27 and 33. Between stages 34 to 41, they are circular and expanded, and the medial margins are slightly superimposed. The margin of the labial flaps is smooth, except in some larvae that presented slightly serrated margins between larval stages 28-40. This condition was observed in $18 \%$ of the tadpoles examined $(n=$ 56 tadpoles). The posterior labium divides in anterior and posterior folds. From stage 27, the anterior fold becomes U-shaped and forms a funnel, while the posterior fold remains as lateral folds in contact with the base of this funnel (Figs 1G, H).

By stage 32, the oral funnel is completely formed and shows no significant changes until the metamorphic climax, when it modifies into the adult mouth. By stage 42 , the labial flaps of the anterior labium begin to regress progressively and become no longer visible at stage 43 (Figs $2 \mathrm{~A}-\mathrm{C}$ ). By stage 43 , the posterior labium spreads and loses the appearance of funnel (Figs $2 \mathrm{E}-\mathrm{G}$ ). Then, the margin of the lower jaw becomes semicircular, similar to the adult mouth.

\section{Development of adhesive glands}

The adhesive glands in E. bicolor develop from stage 18, as two oval, pigmented, and slightly elevated areas posterior and lateral to the stomodeum (Fig. 1A). At stage 22, they have conical shape, and are associated with the ends of the anterior labium (Fig. 1B). Their apices show a glandular central area that produces the adhesive mucus used by the larva to fix to the substrate. The conical shape is maintained until stage 27 (Fig. 1C), when it starts regressing, and at stage 29 it 


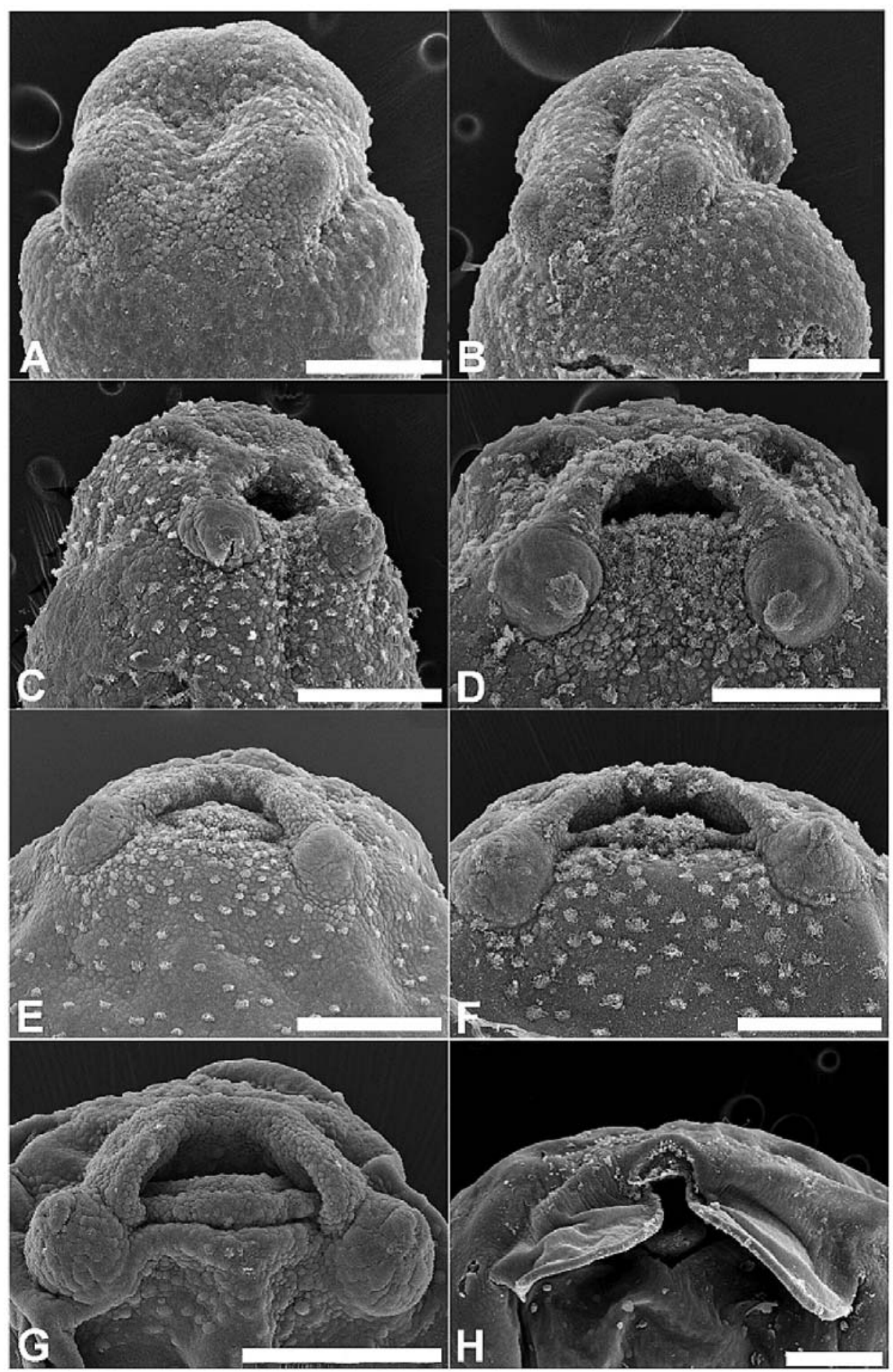

Fig. 1. Scanning electron micrographs of the funnel oral development of Elachistocleis bicolor during the early ontogeny. A - stage 18; B - stage 22; C - stage 23; D - stage 24; E - stage 25; F - stage 26; G - stage 27; H - stage 32. Scales $2 \mathrm{~mm}$.

is only visible as dark spots on the region where it was previously placed.

\section{Development of external gills}

At stage 19, external gills develop as semispherical bulges on each side of the head, posterior to the adhesive glands and optic vesicles (Fig. 3A). By stage 22 , each bulge is subdivided by two vertical grooves, which define the anterior, medial, and posterior folds. By stage 23, each fold develops digitiform projections, which originate the gill filaments (Figs $3 \mathrm{~B}-\mathrm{C}$ ). The first projections appear on the anterior fold, and then on the medial and the posterior ones. The gill filaments attain their fullest length by stage 24 (Fig. $3 \mathrm{E}$ ). By stage 26 , the external gills are covered by the operculum, being externally invisible. 


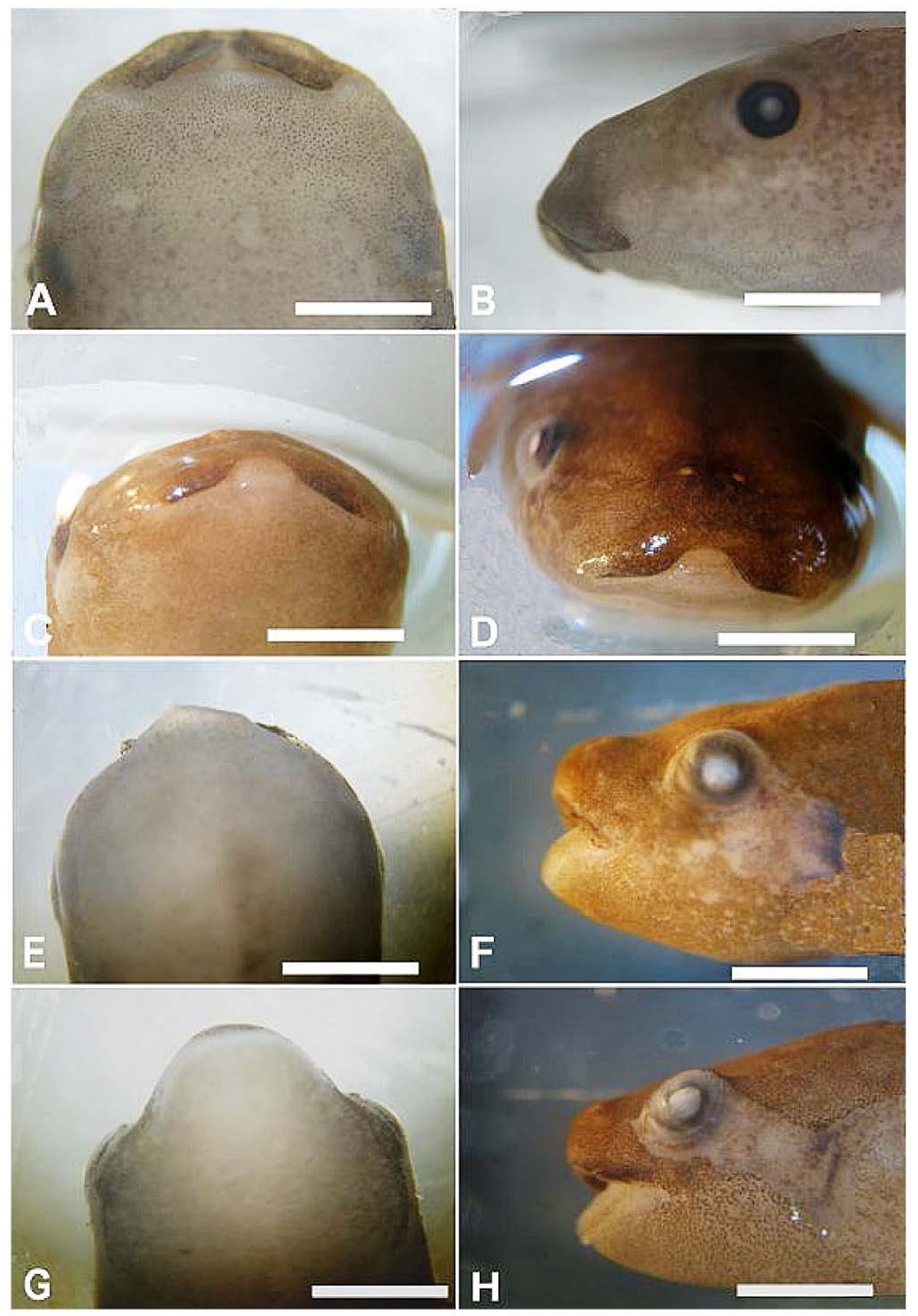

Fig. 2. Oral funnel transformations during the metamorphosis in Elachistocleis bicolor. A,B - early stage 42 in ventral and lateral views; C, D - late stage 42 in ventral and frontal views; E, F - early stage 43 in ventral and lateral views; G, H - late stage 43 in ventral and lateral views. Scales $2 \mathrm{~mm}$.

\section{Development of the operculum and spiracle}

The development of the operculum starts at stage 24 with the formation of a pair of skin folds, anterolateral to the external gills (Figs 3D-F). These folds grow simultaneously and cover the base of the gill filaments. Then, they extend on the ventral region, forming a Vshaped fold (Fig. 4A, B). This fold subsequently becomes transversally straight and covers half of the external gills (Figs 4C, D). By stage 26, the external gills are completely covered (Figs $4 \mathrm{E}, \mathrm{F}$ ), and two lateroventral folds are fused with the anterior transverse one, delimiting the spiracular opening on the ventromedial region of the body. Then, the operculum extends to the posterior region and forms the spiracular tube
(Fig. 4G), which extends surpassing the vent tube, so that the spiracular opening is oriented toward the left side of the tadpole (stage 28). By stage 41 (at the beginning of metamorphosis), the spiracular tube starts a process of regression. Initially, the spiracular tube locates in the medial axis between the hindlimbs; at stage 43 , the spiracular tube is short and its opening is located on the ventral half of the body. By stage 44, only a circular scar between the forelimbs is observed as remains of the spiracular tube. These changes resemble the inverse process observed during their formation.

\section{Development of external nares}

The external nares in E. bicolor develop at stage 


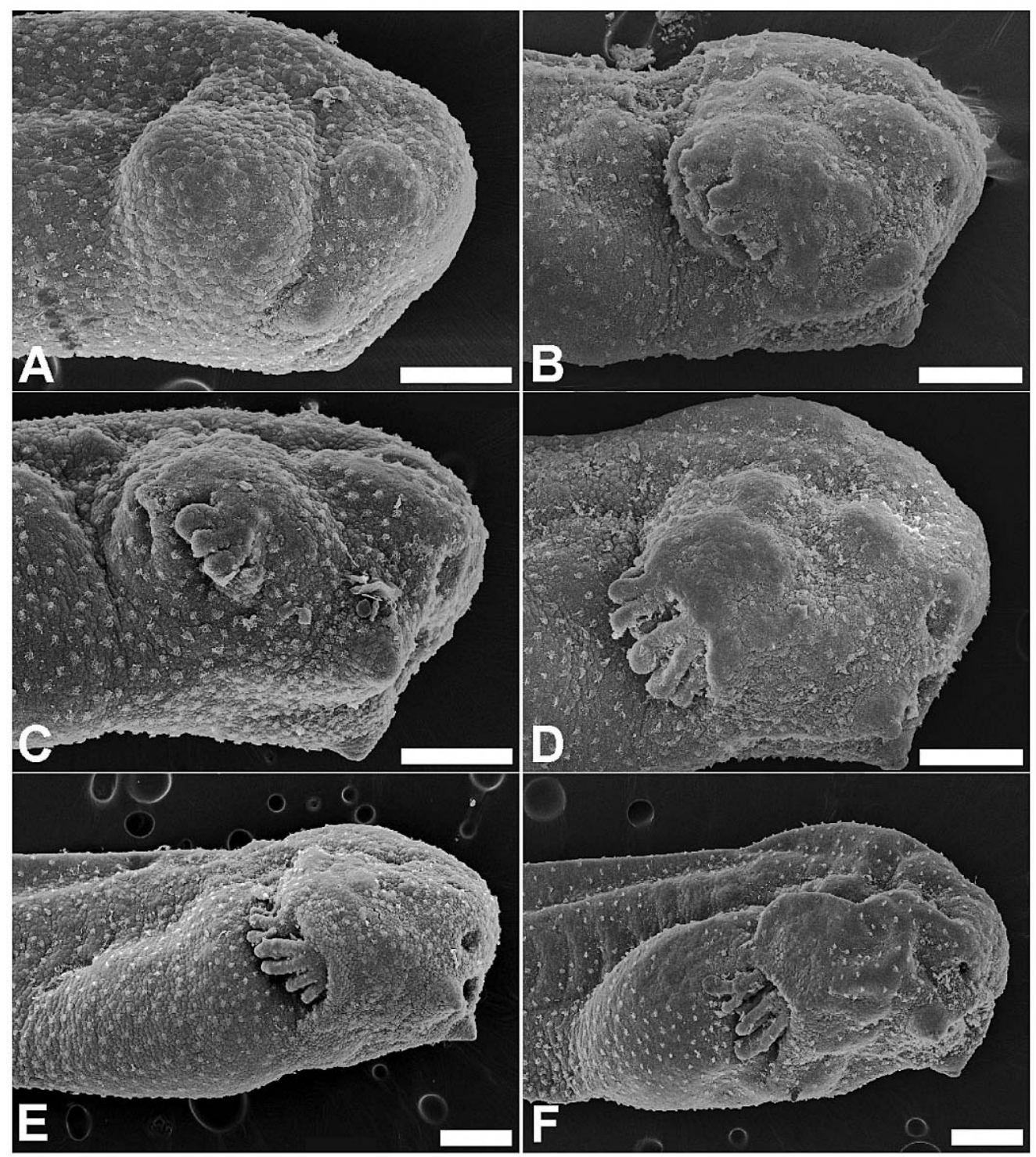

Fig. 3. Scanning electron micrographs of the external gills development of Elachistocleis bicolor. A - stage 19; B - early stage 23; C - late stage $23 ; \mathrm{D}$ - early stage $24, \mathrm{E}$ - late stage $24 ; \mathrm{F}$, stage 25 . Scales $2 \mathrm{~mm}$.

19 as two small, flattened areas, on the anterior region of the head and dorsal to the stomodeal invagination. From stage 22 to stage 26 , they remain as a pair of distinct circular pits. During stages 2740, the pits are indistinct, although their location is indicated by two small dark stains in live specimens. Through pre-metamorphic stages, the stains of the external nares change their location. At the beginning, they are on the dorsal region, nearer the snout than the eyes, and look like two small, dark spots. Later, the spots approach each other and are located approximately halfway between the eyes and the snout. At the beginning of metamorphosis, the dark spots are displaced forward, approaching each other and placed on paired elevations in the anterior edge of the snout. At stage 41, the external nares are clearly open. In juveniles, the external nares are placed on the tip of the snout, with clear borders, surrounded by more pigmented areas than the contiguous skin.

\section{Discussion}

The development of Elachistocleis bicolor is similar to that of other species with free-swimming tadpoles as Microhyla ornata, Dermatonotus muelleri and Uperodon globulosus (Shimizu \& Ota 2003; Fabrezi et al. 2012; Narzary \& Bordoloi 2013). Information about the development of the oral funnel in Microhylidae is fundamental to interpret the origin and evolution of the oral apparatus of anuran tadpoles (Altig 2006). Thibaudeau \& Altig (1988) proposed a common development pattern of ontogenetic development and atrophy of the oral apparatus based on six anuran species with four different types of mouth. The pattern is as follows: stomodeal invagination, oral pad development, jaw sheath delimitation, oral disc formation, jaw sheath keratinization, tooth row ridge development, and formation of marginal papillae in rapid sequence with considerable temporal overlap, and lastly, tooth keratinization, although all features may not be fully formed before 

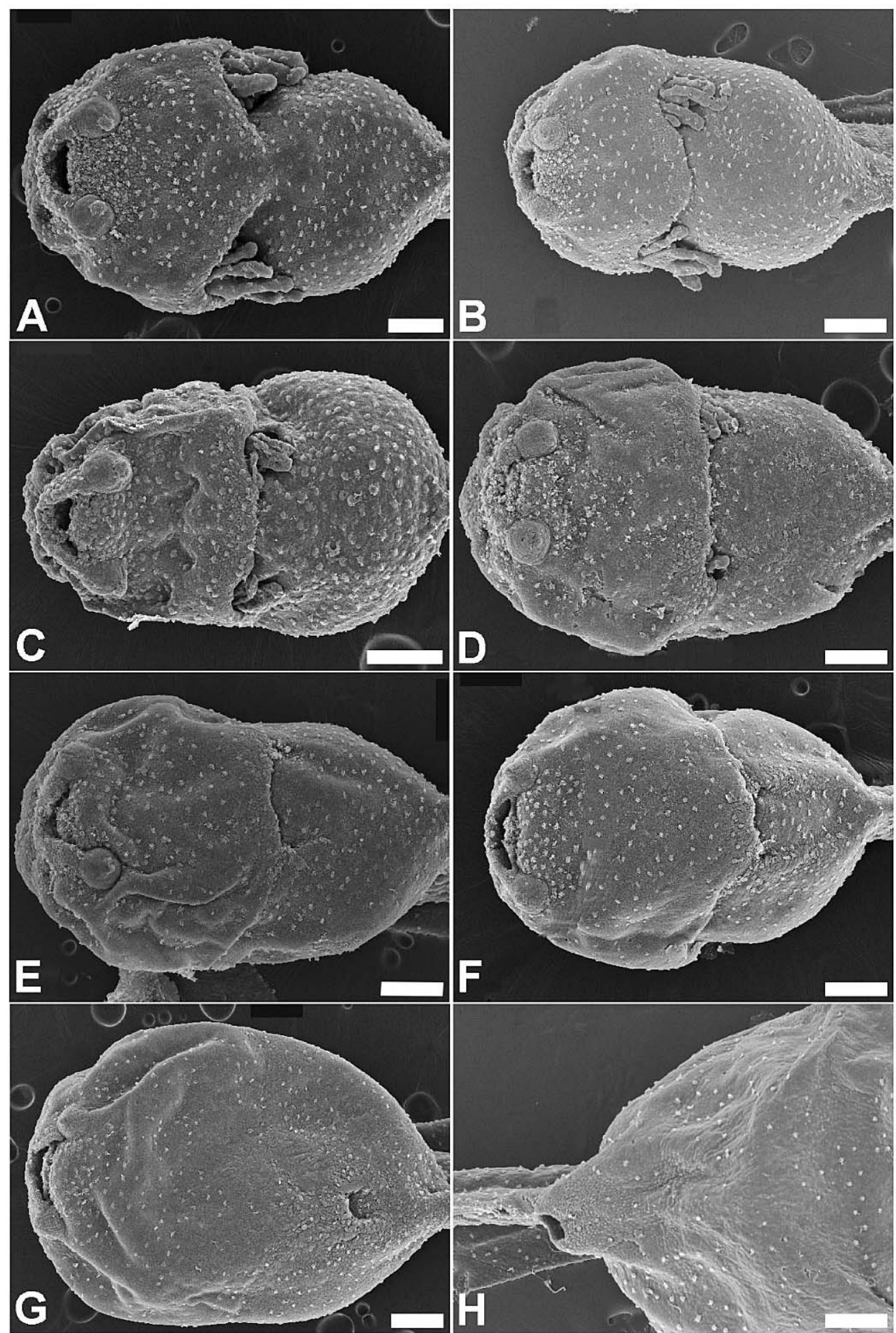

Fig. 4. Scanning electron micrographs of the operculum and spiracle development of Elachistocleis bicolor. A, D - stage 25; E - stage $26 ; \mathrm{F}$ - stage 27; G, H - stage 28. Scales $2 \mathrm{~mm}$.

the next structure appears. Elachistocleis bicolor shows only the early stages of this developmental pattern. After the invagination of the stomodeum, the anterior and posterior labia are defined, but the keratinized structures are not formed. The anterior labium with two labial flaps and a medial notch is shared between $E$. bicolor and other microhylids, as D. muelleri, Elachis- tocleis ovalis, E. surinamensis (Daudin, 1802), E. cesarii (Miranda-Ribeiro, 1920), E. erythrogaster Kwet and Di-Bernardo, 1999, E. haroi Pereyra, Akmentins, Laufer et Vaira, 2013, E. panamensis (Dunn, Trapido et Evans, 1948), Gastrophryne carolinensis Holbrook, 1835, G. elegans (Boulenger, 1882), G. olivacea Hallowell, 1856, Hypopachus ustus (Cope, 1886), H. pictiven- 

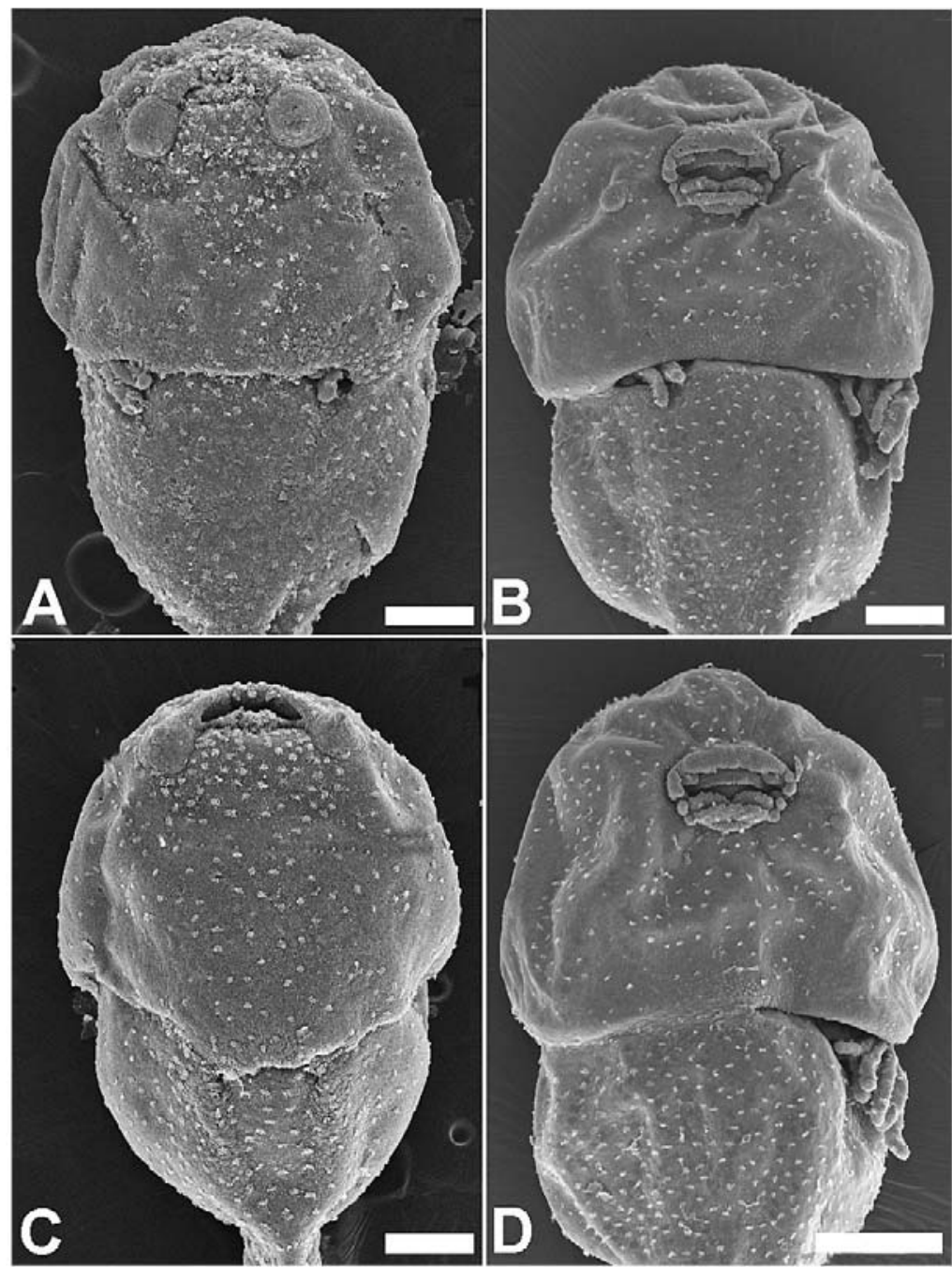

Fig. 5. Scanning electron micrographs of the development of the operculum in Type II (A, C) and Type IV (B, D) tadpoles. To the left, Elachistocleis bicolor tadpoles; to the right, Physalaemus albonotatus tadpoles. Upper row: stage 23; lower row: stage 24 (stages equivalent to Gosner, 1960). Scales $2 \mathrm{~mm}$.

tris (Cope, 1886), Chiasmocleis leucosticte (Boulenger, 1888), C. carvalhoi (Cope, 1886), and Microhyla ornata (Donnelly et al. 1990; Lavilla 1992; Kwet \& DiBernardo 1998; Shimizu \& Ota 2003; Wogel et al. 2004; Vera Candioti 2006; Langone et al. 2007; Fabrezi et al. 2012; Pereyra et al. 2013).

The labial flaps of microhylids are considered homologous with the oral labia of Orton's (1953) Types III and IV tadpoles, and with the lateral labial folds of Rhinophrynus (Orton's Type I), because they all originate from an oral pad delimited at the beginning of the development of the oral structures (Thibaudeau \& Altig 1988). Additionally, vestigial labial crests have been described in microhylid larvae with reduced oral disks and without labial teeth as Ctenophryne sp. and Otophryne robusta Boulenger In Lankester, 1900 (Thibaudeau \& Altig 1988; Donelly et al. 1990), although this character could be a convergence since according to the latest comprehensive phylogeny of Microhylidae (de Sá et al. 2012), Otophryne is placed closer to Kalophrynus from Southeastern Asia than to other new world microhylids. The lack of keratinized structures in the ontogeny of the oral funnel observed in E. bicolor and other microhylid species is considered a truncation of the development (Altig 2006). Heterochronic alterations during development are probably common genetic mechanisms of modification (Thibaudeau \& Altig 1988). The presence of integumentary ciliated cells on the presumptive face of the disc, as observed in E. bicolor, indicates that the disc face is homologous with the general surfaces surrounding the mouth (Altig 2006). During metamorphosis, the oral funnel changes, originating the adult mouth. In E. bicolor, transformations are similar to those described for $D$. muelleri, such as the regression of the oral flaps and the modification the oral funnel to originate the lower jaw (Fabrezi et al. 2012).

The adhesive glands in E. bicolor appear early during embryonic development. Five distinct patterns of development have been reported in anurans (Nokhbatolfoghahai and Downie 2005b). According to this classification, the conical adhesive organs with a broad base and more or less tapering tip of E. bicolor correspond to Type "C". This type of adhesive glands has been reported in Physalaemus biligonigerus (Cope, 1961), 
P. albonotatus (Steindachner, 1864), Dendropsophus microcephalus (Cope, 1886), D. minutus (Peters, 1872) and D. minusculus (Rivero, 1971) (Zaracho et al. 2003; Nokhbatolfoghahai \& Downie 2005b). However, while in these species these glands are developed separately from the oral disk, in E. bicolor they are in contact with the ends of the anterior labium during their ontogeny.

The external gills are transitory embryonic structures, and are considerably diverse in their morphology at anatomical and ultrastructural levels (Nokhbatolfoghahai \& Downie 2008). In microhylids (as E. ovalis and E. bicolor), the number and length of filaments are lower than in bufonids and Xenopus laevis Daudin, 1802 (Nokhbatolfoghahai \& Downie 2008). Microhylid species of the genera Cophixalus and Oreophryne with direct development have no external gills, but a diminutive bulge is visible on gill arches. However, in live, no circulating blood is observed in this area (Anstis et al. 2011).

In Type IV larvae, the operculum folds close from right to left, covering the right gill first (Del Conte \& Sirlin 1951; Gosner 1960; Lavilla \& Rouges 1992; Hall et al. 1997; Zaracho et al. 2003). In contrast, in E. bicolor, a symmetrical process is observed, where both external gills are covered simultaneously by the transverse operculum fold, and two lateral folds that unite with the transversal one appear on the lateroventral region of the body (Figs 5B, D). These joined structures advance towards the posteromedial ventral region to form the spiracle (Figs 5A, C). A similar pattern has been described in free-swimming, non-feeding tadpoles of Chiasmocleis antenori that develop in water-filled bromeliads, although in this species, the external and internal gills are not developed (Krügel \& Richter, 1995). The position of the spiracle in E. bicolor coincides with the description by Williams \& Gudynas (1987). This position is also shared with that in E. surinamensis, E. ovalis and E. erythrogaster (Griffith \& Carvalho 1965; Kenny 1969; Rada de Martinez 1981; Kwet \& Di-Bernardo 1998). Other microhylids, as Ctenophryne carpish (Lehr, Rodriguez et Córdova, 2002), have a short spiracular tube, whose opening is located in the half line below the abdomen; this position is shared with $C$. aequatorialis (Peracca, 1904), but in this latter species also the ventral spiracle has a medial subdivision anterior to the gut, forming tubes each of which connect with a gill (Lehr et al. 2007). The shape and extension of the spiracle in Chiasmocleis leucosticta (Boulenger, 1888) is similar to that in E. bicolor, but the opening position is medial and only visible in ventral view (Langone et al. 2007). In D. muelleri, the spiracle is posteromedial in position and opens slightly anterior and ventral to the vent tube (Fabrezi et al. 2012).

In microhylids with direct development of the genera Austrochaperina, Cophixalus and Oreophryne, the operculum is not discernible during embryonic development, unlike that described in other non-microhylid species with direct development as Eleutherodactylus coqui Thomas, 1966, Eupsophus emiliopugini Formas, 1989 and myobatrachids (Callery \& Elinson 2000; Vera
Candioti et al. 2011; Anstis et al. 2007; Anstis 2008). The apparent absence of opercular folds in tadpoles of species with direct development suggests a deletion during ontogeny (Callery \& Elinson 2000; Anstis et al. 2011).

A medially oriented vent tube is the typical microhylid condition (Inger 1967). In E. bicolor, the vent tube was observed in medial position in Gosner's stage 38-39 tadpoles (Williams \& Gudynas 1987), while Lavilla \& Langone (1991) mentioned that the vent tube opening migrated from left to right during stages $34-39$, changing from a non-microhylid to a typical microhylid position. In E. bicolor, we observed that the vent tube opening is oriented toward the left during most of the development.

The fact that the external nares are closed during most of the tadpole life of microhylids (Wasserssug 1989; Altig \& McDiarmid 1999; Nokhbatolfoghahai \& Downie 2005a) has been proposed as an additional diagnostic character to define Orton's Type II tadpoles of Microhylidae (Wassersug 1989). In E. bicolor, the external nares are closed externally at the beginning of independent feeding, to be re-opened at stage 41 . The unperforated external nares, the divided ventral velum, the structure of branchial food traps and the expanded prenarial region of the buccal roof in microhylid tadpoles have been associated with the efficiency of their buccal pumps in free living tadpoles and suspension feeding (Wassersug 1980, 1989).

The distinct larval characters of Microhylidae appear during the last embryonic stages and first larval stages. Therefore, the consideration of these stages can be of great value in future studies of anuran development in ecological, phylogenetic and evolutionary contexts. Also, the study of the ontogeny of larval structures such as the oral funnel in microhylid tadpoles and in other species with oral funnels with or without vestigial, keratinized structures, are key to identify heterochronic processes, to interpret the variability of larval structures, and to establish or reinforce hypotheses about the origin of larval structures.

\section{Acknowledgements}

We thank A. Hernando and E. Lavilla for their critical comments on the manuscript. We also thank C. Galíndez for the first corrections of the language and M.V. Gonzalez Eusevi for valuable suggestions and comments and for critically reading the English of the final version of the manuscript. Dirección de Biodiversidad (Corrientes province, Argentina) kindly issued the research permits. We are grateful to the staff of the Scanning Electron Microscopy section of the Universidad Nacional del Nordeste (UNNE), Corrientes, Argentina. This research was supported by PI F-019 (Secretaría General de Ciencia y Técnica, UNNE).

\section{References}

Altig R. 2006. Discussions of the origin and evolution of the oral apparatus of anuran tadpoles. Acta Herpetol. 1 (2): 95-105. DOI: http://dx.doi.org/10.13128/Acta Herpetol-1292 
Altig R. \& Johnston G.F. 1989. Guilds of anuran larvae: relationships among developmental modes, morphologies and habitats. Herpetol. Monogr. 3: 81-109. DOI: 10.2307/1466987

Altig R. \& McDiarmid R.W. 1999. Body plan. Development and morphology, Chapter 3, pp. 24-51. In: McDiarmid R.W. \& Altig R. (eds), Tadpoles, The Biology of Anuran Larvae, University of Chicago Press, Chicago and London, 458 pp. ISBN: 9780226557625

Anstis M. 2008. Direct development in the Australian myobatrachid frog Metacrinia nichollsi from Western Australia. Records of the Western Australian Museum 24 (2007-2008) Part 2: 133-150.

Anstis M., Parker F., Hawkes T., Morris I. \& Stephen J.R. 2011. Direct development in some Australopapuan microhylid frogs of the genera Austrochaperina, Cophixalus and Oreophryne (Anura: Microhylidae) from northern Australia and Papua New Guinea. Zootaxa 3052: 1-50.

Anstis M., Roberts J.D. \& Altig R. 2007. Direct development in two myobatrachid frogs, Arenophryne rotunda Tyler and Myobatrachus gouldii Gray, from Western Australia. Records of the Western Australian Museum 23 (2006-2007) Part 3: $259-271$.

Baorong G., Qing W. \& Qiujin Z. 1996. Early embryonic development in Microhyla ornata Chin. J. Zool. 31 (5): 17-21.

Bowatte G. \& Meegaskumbura M. 2011. Morphology and ecology of tadpoles of Ramanella obscura (Anura: Microhylidae). Ceylon J. Sci. (Biol. Sci.) 40 (2): 109-120. DOI: 10.4038/cjsbs.v40i2.3927

Callery E.M. \& Elinson R.P. 2000. Opercular development and ontogenetic re-organization in a direct-developing frog. Dev. Genes Evol. 210 (7): 377-381. DOI: 10.1007/s004270000070

Del Conte E. \& Sirlin J.L. 1951. Serie tipo de los primeros estadios embrionarios en Bufo arenarum. Acta Zool. Lilloana 12: 495499.

de Sá R.O., Streicher J.W., Sekonyela R., Forlani M.C., Loader S.P., Greenbaum E., Richards S. \& Haddad C.F. 2012. Molecular phylogeny of microhylid frogs (Anura: Microhylidae) with emphasis on relationships among New World genera.BMC Evol. Biol. 12: 1-21. DOI: 10.1186/1471-2148-12241

Desnitskiy A.G. 2012. On the diversity of the initial steps of embryonic development in anuran amphibians. Russ. J. Herpetol. 19 (3): 221-231.

Donnelly M.A., de Sá R.O. \& Guyer C. 1990. Description of the tadpoles of Gastrophryne pictiventris and Nelsonophryne aterrima (Anura: Microhylidae), with a review of morphological variation in free-swimming microhylid larvae. American Museum Novitates 2976: 1-19.

Echeverría D.H. \& Lavilla E.O. 2000. Internal oral morphology of tadpoles of Dermatonotus muelleri and Elachistocleis bicolor (Anura: Microhylidae). J. Herpetol. 34 (4): 517-523. DOI: $10.2307 / 1565265$

Fabrezi M., Quinzio S., Goldberg J. \& de Sa R. 2012. The development of Dermatonotus muelleri (Anura: Microhylidae: Gastrophrynae). J. Herpetol. 46: 363-380. DOI: http://dx.doi. org/10.1670/11-194

Fiorito de López L.E. \& Echeverría D.D. 1989. Microanatomía e histogénesis del aparato bucal en las larvas de Bufo arenarum (Anura, Bufonidae). Cuadernos de Herpetologia 4 (2): 4-10.

Gosner K.L. 1960. A simplified table for staging anuran embryos and larvae with notes on identification. Herpetologica 16 (3): 183-190.

Griffiths I. \& De Carvalho A.L. 1965. On the validity of employing larval characters as major phyletic indices in Amphibia, Salientia. Rev. Bras. Biol. 23: 113-21.

Grosjean S., Glos J., Teschke M., Glaw F. \& Vences M. 2007. Comparative larval morphology of Madagascan toadlets of the genus Scaphiophryne: phylogenetic and taxonomic inferences. Zool. J. Linn. Soc. Lond. 151 (3): 555-576. DOI: 10.1111/j.1096-3642.2007.00329.x

Günther R. 2006. Derived reproductive modes in New Guinean anuran amphibians and description of a new species with paternal care in the genus Callulops (Microhylidae). J. Zool. 268 (2): 153-170. DOI: 10.1111/j.1469-7998.2005.00007.x
Hall J.A., Larsen J.H. \& Fitzner R.E. 1997. Postembryonic ontogeny of the spadefoot toad, Scaphiopus intermontanus (Anura: Pelobatidae): External morphology. Herpetol. Monogr. 11 (1997): 124-178. DOI: 10.2307/1467009

Inger R. 1967. The development of a phylogeny of frogs. Evolution 21 (2): 369-384 DOI: 10.2307/2406685

Johnson G.R. \& Richards S.J. 1993. Observations on the breeding biology of a microhylid frog (genus Oreophryne) from New Guinea. Trans. Roy. Soc. South Australia 117 (2): 105-107.

Kenny J.S. 1969. The amphibia of Trinidad. Studies on the Fauna of Curaçao and other Caribbean Islands, No. 108, 78 pp.

Krügel P. \& Richter S. 1995. Syncope antenori-A bromeliad breeding frog with free-swimming, nonfeeding tadpoles (Anura, Microhylidae). Copeia 4: 955-963. DOI: 10.2307/ 1447045

Kwet A. \& Di-Bernardo M. 1998. Elachistocleis erythrogaster, a new microhylid species from Rio Grande do Sul, Brazil. Studies on Neotropical Fauna and Environment 33 (1): 7 18. DOI: $10.1076 /$ snfe.33.1.7.2169

Langone J.A., Lavilla E.O., Echeverría D.D., Mangione S. \& Segalla M.V. 2007. Morfología externa e interna de la larva de Chiasmocleis leucosticta (Boulenger, 1888) (Amphibia, Anura, Microhylidae). Publicación Extra, Museo Nacional de Historia Natural y Antropología (Montevideo) 2: 1-17.

Laufer G., Pereyra L.C., Akmentins M.S. \& Borteiro C. 2013. A comment on the oral dermal flaps of Elachistocleis Parker, 1927 (Anura: Microhylidae) larvae. Zootaxa 3710 (5): 498500. DOI: http://dx.doi.org/10.11646/zootaxa.3710.5.7

Lavilla E.O. 1992. The tadpole of Dermatonotus muelleri (Anura: Microhylidae). Bolletino del Museo Regionale di Scienze Naturali di Torino 10: $63-71$.

Lavilla E.O. \& Langone J.A. 1991. Ontogenetic changes in spiracular and proctodeal tube orientation in Elachistocleis bicolor (Anura: Microhylidae). J. Herpetol. 25 (1): 119-121. DOI: $10.2307 / 1564811$

Lavilla E.O. \& Langone J.A. 1995. Estructura del condrocráneo y esqueleto visceral de larvas de Elachistocleis bicolor (Valenciennes, 1938) (Anura: Microhylidae). Cuadernos de Herpetología 9 (1): 45-49.

Lavilla E.O. \& Rougés M. 1992. Reproducción y desarrollo de anuros argentinos. Asociación Herpetológica Argentina Serie Divulgación Científica 5: 1-66.

Lehr E., Trueb L., Venegas P. \& Arbeláez E. 2007. Descriptions of the tadpoles of two Neotropical Microhylid frogs, Melanophryne carpish and Nelsonophryne aequatorialis (Anura: Microhylidae). J. Herpetol. 41 (4): 581-589.

Mac Culloch R.D., Lathrop A., Minter L.R. \& Khan S.Z. 2008. Otophryne (Anura: Microhylidae) from the highlands of Guyana: redescriptions, vocalizations, tadpoles and new distributions. Papeis Avulsos de Zoologia (Săo Paulo) 48 (22): 247-261.

Magalhães F.M., Santana D.J., Neto A.M. \& Garda A.A. 2012. The tadpole of Elachistocleis cesarii Miranda-Ribeiro, 1920 (Anura, Microhylidae). Zootaxa 3187: 54-56.

Marinelli M.D., Tei M. \& Sensi P. 1985. SEM observation on the development and the regression of the oral disc of Bufo vulgaris larvae. Acta Embryol. Morphol. Exp. 6 (1): 31-39.

Narzary J. \& Bordoloi S. 2013. Study of normal development and external morphology of tadpoles of Microhyla ornata and Uperodon globulosus of the family Microhylidae (Amphibia: Anura) from North East India. Int. J. Adv. Biol. Res. 3 (1): 61-73.

Nascimento F.A.C. \& Shuk G.O. 2006. O girino de Chiasmocleis alagoanus Cruz, Caramaschi \& Freire, 1999 (Anura: Microhylidae) [The tadpole of Chiasmocleis alagoanus Cruz, Caramaschi \& Freire, 1999 (Anura: Microhylidae)]. Biota Neotrop. 6 (3): 1-5. DOI: 10.1590/S1676-06032006000300021

Nokhbatolfoghahai M. \& Downie J.R. 2005a. Embryonic external nares in the microhylid Elachistocleis ovalis, with a review of narial development in microhylid tadpole. Herpetol. J. 15: 191-194.

Nokhbatolfoghahai M. \& Downie J.R. 2005b. Larval cement gland of frogs: comparative development and morphology. J. Morphol. 263 (3): 270-283. DOI: 10.1002/jmor.10305 
Nokhbatolfoghahai M. \& Downie J.R. 2008. The external gills of anuran amphibians: comparative morphology and ultrastructure. J. Morphol. 269 (10): 1197-1213. DOI: 10.1002/jmor.10655

Orton G. 1953. The systematics of vertebrate larvae. Sys. Zool. 2 (2): 63-75. DOI: $10.2307 / 2411661$

Padhye A.D. \& Ghate H.V. 1989. Preliminary photographic record and description of various developmental stages of the frog Microhyla ornata (Duméril and Bibron). Herpeton 2: $2-7$

Pereyra L.C., Akmentins M.S., Laufer G. \& Vaira M. 2013. A new species of Elachistocleis (Anura: Microhylidae) from north-western Argentina. Zootaxa 3694 (6): 525-544. DOI: http://dx.doi.org/10.11646/zootaxa.3694.6.2

Rada de Martinez D. 1981. Renacuajos de algunos anfibios de Clarines. (Edo. Anzoátegui, Venezuela). Memoria - Sociedad de Ciencias Naturales La Salle 41 (115): 57-75.

Rodrigues D.J., Menin M., Lima A.P. \& Mokross K.S. 2008. Tadpole and vocalizations of Chiasmocleis hudsoni (Anura, Microhylidae) in Central Amazonia, Brazil. Zootaxa 1680: 5558.

Rossa-Feres D.C. \& Nomura F. 2006. Characterization and taxonomic key for tadpoles (Amphibia: Anura) from the northwestern region of Săo Paulo State, Brazil. Biota Neotrop. 6 (1): 1-26. DOI: http://dx.doi.org/10.1590/S1676-0603200 6000100014

Salica M.J., Haad M.B., Vera Candioti F. \& Faivovich J. 2011. Early development of two species of Phyllomedusa (Anura: Phyllomedusinae). Salamandra 47 (3): 144-154.

Shaolong L., Zhiming S., Jiazao Z., Mingyou H., Quan Z. \& Young L. 1996. Studies on early embryonic development in Microhyla ornata. Journal of Sichuan University (Natural Science Edition) 33 (3): 323-329.

Shimizu S. \& Ota H. 2003. Normal development of Microhyla ornata: the first description of the complete embryonic and larval stages for the microhylid frogs (Amphibia: Anura). Bull. Herpetol. Soc. Japan 22 (2): 73-90. DOI: 10.5358/hsj.22.73

Takahama H., Sasaki F., Tachibana T., Iseki H., Horiguchi T., Kinoshita T. \& Watanabe K. 1987. Fine structure and degeneration of the horny teeth and the epidermis of the labial ridge of the anuran tadpole. Tsurumi Shigaku 13 (1): 49-63. PMID: 3509793

Thibaudeau G. \& Altig R. 1988. Sequence of ontogenetic development and atrophy of the oral apparatus of six anuran tadpoles. J. Morphol. 197 (1): 63-69. DOI: 10.1002/jmor.10519 70106
Towsend D.S. \& Stewart M.M. 1985. Direct development in Eleutherodactylus coqui (Anura: Leptodactylidae): a stagning table. Copeia 1985 (2): 423-436. DOI: 10.2307/1444854

Vera Candioti M.F. 2006. Morfología larval de Chiasmocleis panamensis, con comentarios sobre la variabilidad morfológica interna en renacuajos de Microhylidae (Anura). Alytes 24 (1): $91-108$.

Vera Candioti M.F., Núñez J.J. \& Úbeda C. 2011. Development of the nidicolous tadpoles of Eupsophus emiliopugini (Anura: Cycloramphidae) until metamorphosis, with comments on systematic relationships of the species and its endotrophic developmental mode. Acta Zool. (Stockh.) 92: 27-45. DOI: 10.1111/j.1463-6395.2010.00448.x

Wassersug R.J. 1980. Internal oral features of larvae from height anuran families: functional, systematic, evolutionary and ecological considerations. Miscellaneous Publication University of Kansas Museum of Natural History 68: 1-146.

Wassersug R.J. 1989. What, if anything is a microhylid (Orton type II) tadpole?, pp. 534-538. In: Splechtna H. (ed.), Trends in Vertebrate Morphology: Proceedings of the $2^{\text {nd }}$ International Symposium on Vertebrate Morphology, Vienna, 1986, G. Fischer, Stuttgart, New York, 647 pp. ISBN: 0895742888 (U.S.)

Wiliams J.D. \& Gudynas E. 1987. Descripción de la larva de Elachistocleis bicolor (Valenciennes, 1838) (Anura: Microhylidae). Amphibia-Reptilia 8 (3): 225-229. DOI: 10.1163/156 853887X00261

Wogel H., Abrunhosa P. \& Prado G. 2004. The tadpole of Chiasmocleis carvalhoi and the advertisement calls of three species of Chiasmocleis (Anura, Microhylidae) from the Atlantic rainforest of southeastern Brazil. Phyllomedusa: Journal of Herpetology 3 (2): 133-140. DOI: http://dx.doi.org/10. 11606/issn.2316-9079.v3i2p133-140

Xu M.Y. \& Xu J. 2012. Preliminary observations on postembryonic development of Microhyla ornata in North Guangdong. Sichuan J. Zool. 31 (4): 589-592. DOI: 10.3969/j.issn. 1000-7083.2012.04.015

Zaracho V.H., Céspedez J.A. \& Álvarez B.B. 2003. Descripción de caracteres morfológicos en larvas prometamórficas de Physalaemus biligonigerus (Anura: Leptodactylidae). FACENA 19: 123-134.

Received October 9, 2014 Accepted June 15, 2015 